\title{
PENGARUH PENGERINGAN DAN LAMA MASERASI DENGAN PELARUT GANDA ETANOL DAN HEKSANA TERHADAP SENYAWA BIOAKTIF DAGING BIJI PALEM PUTRI (VEITCHIA MERILLII)
}

\section{Effect of Drying and Maceration Time Using Dual Solvents Ethanol and Hexane on the Bioactive Compounds of Palem Putri Nuts (Veitchia merillii)}

\author{
Ghali Ghazian AI Hazmi, Harijono \\ Jurusan Teknologi Hasil Pertanian, FTP Universitas Brawijaya Malang \\ Jl. Veteran, Malang 65145 \\ *Penulis korespondensi, Email: ghali.alhazmi@gmail.com
}

\begin{abstract}
ABSTRAK
Palem Putri (Veitchia merilli) atau lebih dikenal dengan Christmas Palm merupakan tanaman famili Araceae yang memiliki banyak manfaat karena kaya akan kandungan senyawa bioaktif. Kandungan senyawa bioaktif dari palem putri bergantung pada beberapa faktor seperti pengaruh pengeringan dan lama waktu ekstraksi. Penelitian menggunakan metode Rancangan Acak Kelompok Faktorial (RAKF) dengan 2 faktor, pengaruh pengeringan (segar dan kering) dan lama waktu maserasi (24, 36, dan 48 jam). Hasil penelitian menunjukkan bahwa perlakuan pengaruh pengeringan dan lama waktu maserasi berpengaruh nyata $(\alpha=0.05)$ terhadap rendemen fraksi etanol dan fraksi $n$-heksana, total fenol, total flavonoid, kadar saponin dan aktivitas antioksidan. Hasil perlakuan terbaik diperoleh dari daging biji palem putri kering dengan lama waktu maserasi 36 jam yang memiliki rendemen fraksi etanol sebesar $10.8 \% \mathrm{bk}$, rendemen ekstrak heksana $1.04 \% \mathrm{bk}$, total fenol $196.15 \mathrm{mgGAE} / \mathrm{gram}$ bk, total flavonoid sebesar $102.21 \mathrm{mgQE} / \mathrm{gram}$ bk, kadar saponin sebesar $1.57 \%$ bk, aktivitas antioksidan sebesar $64.49 \%$, dan total karotenoida sebesar 0.03 $\mu \mathrm{g} / \mathrm{gram}$.
\end{abstract}

Kata kunci: Maserasi, Palem putri, Pengaruh pengeringan, Senyawa bioaktif

\begin{abstract}
ABSTRACK
Palem Putri (Veitchia Merilli), commonly known as Christmas Palm, is a family of Araceae plants that have many benefits because they are rich in bioactive compounds. The compounds vary depending on several factors such as drying and extraction techniques. This study used a Factorial Randomized Block Design (FRBD) with 2 factors, namely effect of drying consisting of 2 levels (fresh and dried) and maceration duration consisting of 3 levels (24, 36, and 48 hours). The results showed that drying methods and maceration duration had a significant effect $(\alpha=0.05)$ on yield of ethanol fraction and yield of hexane extract, total phenol, total flavonoids, total saponins and antioxidant activity. The best treatment results were obtained from dried palem putri nuts those extracted within 36 hours maceration time which had yield of ethanol fraction $10.8 \% d w$, yield of hexane fraction $1.04 \% d w$, total phenol 196.15 mgGAE/g dw, total flavonoids $102.21 \mathrm{mgQE} / \mathrm{g} d \mathrm{w}$, total saponins $1.57 \% \mathrm{dw}$, antioxidant activity $64.49 \%$, and total carotenoid $0.03 \mu \mathrm{g} / \mathrm{g}$.
\end{abstract}

Keywords: Maceration, Palem putri, Effect of drying, Bioactive compound

\section{PENDAHULUAN}

Palem merupakan tanaman yang tergolong dalam famili Araceae yang banyak ditanam di Indonesia dan banyak digunakan sebagai tanaman hias di pekarangan rumah maupun sebagai pembatas jalan raya. Anggota keluarga tanaman palem lainnya seperti pinang dan 
kurma, sudah dimanfaatkan buahnya sebagai obat sedangkan buah palem putri belum banyak dimanfaatkan. Dilaporkan bahwa biji palem putri memiliki senyawa fitokimia seperti flavonoid dan polifenol, serta aktifitas antioksidan yang sangat tinggi (Adawiah, 2016).

Senyawa fitokimia yang bersifat sebagai bioaktif tersebut dapat diekstraksi dan dijadikan suplemen atau bahan campuran pangan fungsional. Pada industri ekstraksi bahan bioaktif, umumnya cadangan bahan baku disimpan dalam keadaan kering karena bahan baku segar mudah rusak dan tidak tahan lama. Pengeringan dapat menyebabkan perubahan pada bahan bioaktif dan senyawa volatil. Tingkat perubahannya tergantung antara lain pada cara pengeringan. Karakteristik bahan kering berbeda dengan bahan segar dan akan berpengaruh pada difusi pelarut selama ekstraksi. Metode pengeringan berpengaruh signifikan terhadap kandungan senyawa bioaktif dan aktivitas antioksidan (Pham dkk., 2017). Pengering kabinet merupakan metode sederhana, mudah dioperasikan dan suhunya terkendali walaupun lebih mahal daripada penjemuran.

Senyawa bioaktif tersebut dapat diperoleh dengan proses ekstraksi. Metode ekstraksi terdiri dari berbagai macam, salah satunya adalah metode ekstraksi dengan cara maserasi. Ekstraksi bahan biokatif secara maserasi masih popular karena relatif sederhana, cukup dengan perendaman sampel didalam pelarut pada suhu kamar, walaupun waktunya lama (Voight, 1995). Keberhasilan ekstraksi secara maserasi sangat dipengaruhi antara lain oleh jenis pelarut dan lama waktu ekstraksi. Ekstraksi dengan pelarut ganda secara simultan dapat lebih menghemat waktu jika dibandingkan dengan ekstraksi dengan pelarut tunggal secara berseri atau berurutan. Penggunaan pelarut ganda dengan kepolaran berbeda dapat menghasilkan ekstrak yang maksimal karena senyawa polar dan nonpolar secara simultan akan terekstrak dan terlarut pada masing-masing pelarut sesuai kepolarannya. Umumnya kuantitas dan kualitas ekstrak ditentukan oleh lama waktu ekstraksi. Penelitian ini dimaksudkan untuk membandingkan rendemen ekstrak daging buah biji palem putri menggunakan pelarut ganda etanol dan n-heksana. Kajian lebih lanjut dilakukan untuk mengidentifikasi jenis dan kandungan senyawa bioaktif serta aktifitas antioksidan ekstrak fraksi etanol.

\section{BAHAN DAN METODE}

\section{Alat}

Peralatan yang digunakan dalam penelitian ini adalah shaker waterbath (Memmerth), timbangan analitik (Denver), vacuum rotary evaporator (IKA), pengering kabinet (Memmerth) dan spektrofotometer UV-Vis (Shimadzu).

\section{Bahan}

Buah Palem putri (Veitchia merillii) diperoleh kota Malang dengan karakteristik warna kulit buah merah menyala, ukuran $\pm 3 \mathrm{~cm}$ dan berat buah 5.5-7 gram. Pelarut etanol dan $\mathrm{n}$ heksana berkualitas teknis. Bahan kimia untuk analisis berkualitas p.a seperti aquades mineral Magnesium, reagen Dragendorff dan reagen Meyer, asam asetat anhidrat, $\mathrm{HCl}$ dan $\mathrm{FeCl} 3, \mathrm{HCl}$ pekat dan $\mathrm{H} 2 \mathrm{SO} 4$ pekat.

\section{Metode Penelitian}

Metode penelitian menggunakan Rancangan Acak Kelompok Faktorial (RAKF) yang menggunakan 2 faktor. Faktor pertama adalah pengaruh pengeringan dengan dua level, daging biji segar dan daging biji kering. Faktor kedua adalah lama waktu maserasi yang terdiri dari 3 level: 24 jam, 36 jam dan 48 jam. Setiap kombinasi perlakuan diulang 4 kali.

Data hasil pengamatan dianalisis dengan menggunakan analisis sidik ragam atau ANOVA (Analysis of Variance). Metode Rancangan Acak Kelompok Faktorial dilanjutkan dengan uji DMRT (Duncan Multiple Range Test) jika terdapat interaksi atau jika tidak terdapat interaksi dengan selang kepercayaan $5 \%$ dilakukan uji lanjut BNT. Sampel dengan perlakuan terbaik ditentukan menggunakan metode zeleny. 


\section{Perlakuan Awal Daging Biji Palem Putri}

Buah palem putri disortasi dan dicuci untuk memisahkan dan menghilangkan debu serta buah yang memiliki cacat fisik. Buah palem putri selanjutnya dikupas untuk memisahkan kulit buah, serabut, dan tempurung biji dari daging bijinya. Daging biji palem putri dipotong dan dihancurkan menggunakan penumbuk. Hancuran daging biji palem putri kemudian dibagi menjadi dua kelompok untuk faktor P1 dan P2. Hancuran daging biji palem putri untuk faktor P1 dihaluskan menggunakan lesung hingga diperoleh serbuk kasar daging biji palem putri segar lolos ayakan 20 mesh. Hancuran daging biji palem putri untuk faktor P2 dikeringkan selama 3.5 jam menggunakan cabinet dryer dengan suhu $50^{\circ} \mathrm{C}$. Hancuran daging biji palem putri kering dihaluskan menggunakan blender hingga diperoleh serbuk kasar biji palem putri kering lolos ayakan 20 mesh.

\section{Pembuatan Ekstrak Kering}

Serbuk kasar biji palem putri (kering dan segar) masing-masing ditimbang sebanyak 20 gram dan dimasukkan kedalam erlenmeyer $250 \mathrm{ml}$. Pelarut etanol 70\% disiapkan sebanyak $100 \mathrm{ml}$ dan dimasukkan kedalam erlenmeyer yang telah berisi sampel. Pelarut $\mathrm{n}$-heksan disiapkan sebanyak $150 \mathrm{ml}$, dimasukkan kedalam erlenmeyer yang berisi sampel dan etanol. Sampel kemudian diaduk agar pelarut dapat menjangkau seluruh bagian sampel. Sampel dimasukkan kedalam shaker waterbath menggunakan suhu $35^{\circ} \mathrm{C}$ dan dimaserasi sesuai variabel waktu ekstraksi yang telah ditentukan (24, 36, dan 48 jam). Ekstrak yang didapat dipisahkan dengan bahan menggunakan pompa vacuum dan kertas saring halus. Ekstrak kemudian dipisahkan berdasarkan fraksi yang terbentuk menggunakan corong pemisah dan dimasukkan kedalam botol kaca amber. Fraksi etanol dipekatkan menggunakan vacuum rotary evaporator suhu $45^{\circ} \mathrm{C} 50 \mathrm{rpm}$, sedangkan fraksi n-heksan dipekatkan dengan suhu $40^{\circ} \mathrm{C} 50 \mathrm{rpm}$ hingga didapatkan ekstrak pekat. Ekstrak etanol pekat dikering anginkan hingga menjadi ekstrak etanol kering.

\section{Uji Skrining Fitokimia Ekstrak Etanol}

Identifikasi total fenol dilakukan menggunakan metode Ferric Chloride test. Filtrat diambil sebanyak $2 \mathrm{ml}$, ditambahkan larutan $\mathrm{FeCl}_{3} 1 \%$ dan dikocok. Uji positif ditandai dengan perubahan warna sampel menjadi biru tua (Adawiah, 2016). Identifikasi total flavonoid dilakukan menggunakan metode Wilstater test. Filtrat diambil sebanyak $1 \mathrm{ml}$, ditambahkan sedikit serbuk Mg, dan ditambahkan 5 tetes $\mathrm{HCl}$ pekat. Uji positif ditandai dengan perubahan warna sampel menjadi jingga (Modifikasi Adawiah, 2016). Identifikasi saponin dilakukan menggunakan metode Foam test. Sebanyak $2 \mathrm{ml}$ filtrat ditambahkan $1 \mathrm{ml}$ aquades dan dikocok. Uji positif ditandai dengan terbentuknya busa stabil selama 10 menit (Modifikasi Pandey and Shalini, 2014). Pengujian jenis senyawa saponin dilakukan dengan metode Liebermann Burchard test. Filtrat diambil sebanyak $1 \mathrm{ml}$, ditambahkan $0.5 \mathrm{ml}$ asetat anhidrat dan 1-2 tetes $\mathrm{H}_{2} \mathrm{SO}_{4}$. Perubahan warna sampel menjadi hitam-merah bata menunjukkan sampel positif triterpenoid; kehijauan menunjukkan sampel positif steroid (Modifikasi Pandey and Shalini, 2014). Identifikasi alkaloid dilakukan dengan Metode Mayer dan Dragendroff test. Filtrat diambil sebanyak $2 \mathrm{ml}$ dan ditambahkan $\mathrm{HCl} 2 \% 1 \mathrm{ml}$. Kemudian dilakukan pemisahan menjadi 2 bagian dengan masing-masing bagian ditambah pereaksi Mayer dan Dragendroff sebanyak 2-3 tetes. Hasil uji positif ditunjukkan dengan adanya endapan pada masing-masing bagian (Ergina, 2014).

\section{Analisis Total Fenol}

Ekstrak etanol kering ditimbang sebanyak $25 \mathrm{mg}$ dan dilarutkan hingga volume $25 \mathrm{ml}$. Sampel diencerkan hingga konsentrasi $20 \mathrm{ppm}$. Sampel diambil $0.5 \mathrm{ml}$, ditambahkan $2.5 \mathrm{ml}$ reagen Folin-Ciocalteau (diencerkan 1:10) dan diinkubasi selama 5 menit. Selanjutnya ditambahkan $2 \mathrm{ml}$ larutan $\mathrm{Na}_{2} \mathrm{CO}_{3} 7.5 \%$, divortex, dan diinkubasi selama 30 menit suhu ruang dalam kondisi gelap. Diukur absorbansi menggunakan panjang gelombang $754 \mathrm{~nm}$. 


\section{Analisis Total Flavonoid}

Ekstrak etanol kering ditimbang sebanyak $25 \mathrm{mg}$ dan dilarutkan hingga volume $25 \mathrm{ml}$. Sampel diambil sebanyak $1 \mathrm{ml}$, ditambahkan $0,3 \mathrm{ml}$ larutan $\mathrm{NaNO}_{3}$, dan diinkubasi selama 6 menit. Ditambahkan $0.3 \mathrm{ml}$ larutan $\mathrm{AlCl}_{3}$ dan diinkubasi selama 6 menit. Selanjutnya ditambahkan $4 \mathrm{ml}$ larutan $\mathrm{NaOH} 1 \mathrm{M}, 2.4 \mathrm{ml}$ aquades, dan diinkubasi pada suhu ruang dalam kondisi gelap. Diukur nilai absorbansi menggunakan panjang gelombang $447 \mathrm{~nm}$

\section{Analisis Kadar Saponin}

Ekstrak etanol kering ditimbang sebanyak $37.5 \mathrm{mg}$ dan dilarutkan hingga volume $25 \mathrm{ml}$. Sampel diambil sebanyak $0.2 \mathrm{ml}$, ditambahkan $0.2 \mathrm{ml}$ reagen vanillin-asam asetat $5 \%, 1.2 \mathrm{ml}$ asam perklorat $70-72 \%$, dan dipanaskan menggunakan waterbath suhu $70^{\circ} \mathrm{C}$ selama 15 menit. Selanjutnya ditambahkan $5 \mathrm{ml}$ etil asetat kemudian divortex. Diukur nilai absorbansi menggunakan panjang gelombang $550 \mathrm{~nm}$.

\section{Analisis Aktivitas Antioksidan}

Ekstrak etanol kering ditimbang sebanyak $25 \mathrm{mg}$ dan dilarutkan hingga volume $25 \mathrm{ml}$. Sampel diencerkan hingga konsentrasi $5 \mathrm{ppm}$. Sampel diambil sebanyak $4 \mathrm{ml}$, ditambahkan dengan $1 \mathrm{ml}$ 1.1-diphenyl-2-pyorihidrazil (DPPH) 0,2 mM, dan diinkubasi selama 30 menit. Diukur nilai absorbansi menggunakan panjang gelombang $517 \mathrm{~nm}$.

\section{HASIL DAN PEMBAHASAN}

\section{Karakteristik Daging Biji Palem Putri}

Hasil analisis kadar air daging biji palem putri segar dan kering disajikan pada Tabel 1. Kadar air daging biji palem putri segar tidak jauh berbeda dengan hasil yang dikemukakan oleh Silva et al. (2014).

\begin{tabular}{|c|c|c|}
\hline $\begin{array}{l}\text { Daging Biji } \\
\text { Palem } \\
\text { Putri }\end{array}$ & $\begin{array}{c}\text { Kadar Air (\%) } \\
\text { Hasil } \\
\text { Penelitian1) }\end{array}$ & $\begin{array}{c}\text { Kadar Air (\%) } \\
\text { Penelitian Terdahulu } \\
\text { 2) }\end{array}$ \\
\hline Segar & 44.26 & 44.3 \\
\hline Kering & 10.21 & . \\
\hline
\end{tabular}

Kadar air serbuk kering daging biji palem putri menurut hasil penelitian didapatkan sebesar $10.21 \%$.

\section{Analisis Kualitatif Ekstrak Etanol Daging Biji Palem Putri}

Uji kualitatif bertujuan untuk mengetahui kandungan fitokimia dari ekstrak etanol daging biji palem putri sebelum dilakukan analisis penentuan kadar senyawa bioaktif. Data analisis kualitatif kandungan fitokimia ekstrak etanol daging biji palem putri disajikan pada Tabel 2.

Tabel 2. Uji Kualitatif Kandungan Fitokimia Ekstrak Etanol Daging Biji Palem Putri

\begin{tabular}{lllll}
\hline Pengujian & Metode & Hasil & Keterangan & Literatur \\
\hline Alkaloida & Mayer & Tidak terbentuk endapan & - & - a) \\
& Dragendorff & Tidak terbentuk endapan & - & - b) \\
Polifenol & FeCl $_{3}$ test & Biru tua & + & + \\
Flavonoida & Wilstater & Jingga terbentuk busa & + & + \\
& test & & & + \\
Saponin & Foam test & Terdapat busa & + & + \\
Jenis & Lieberman & Terbentuk cincin coklat, & + & + \\
Saponin & bunchard & berwarna merah tua & & \\
\hline
\end{tabular}

Keterangan: a)Balqis, dkk (2016) b'Adawiah (2016) 


\section{Penentuan Gugus Fungsi dengan FTIR}

Hasil pembacaan gugus fungsi FTIR ekstrak etanol daging biji palem putri dapat dilihat pada Gambar 1.

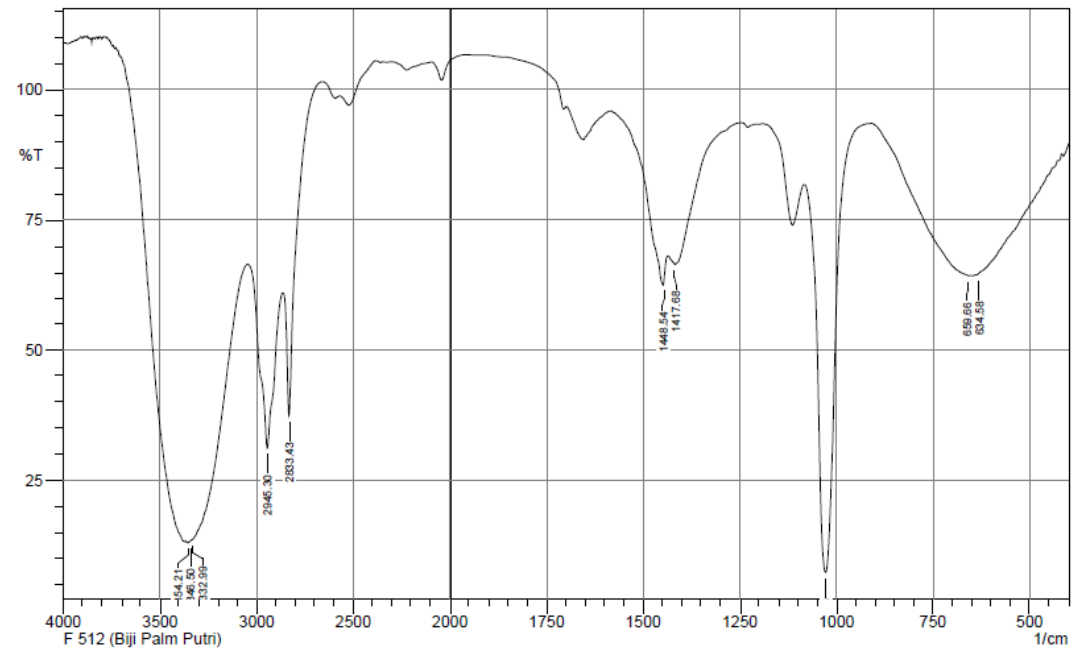

Gambar 1. Analisis Gugus Fungsi Ekstrak Etanol Daging Biji Palem Putri Metode FTIR

Hasil analisis gugus fungsi FTIR menunjukkan bahwa ekstrak etanol daging biji palem putri mengandung senyawa seperti alkena, senyawa aromatik, asam karboksilat, alkohol, ester, alkana, fenol, dan amina. Penentuan gugus ditandai dengan terbentuknya puncak pada panjang gelombang spesifik. Pembacaan hasil puncak FTIR pada daging biji palem putri disarikan pada Tabel 3.

Tabel 3. Pembacaan Hasil Puncak FTIR Ekstrak Etanol Daging Biji Palem Putri

\begin{tabular}{ll}
\hline Gelombang Puncak $\left(\mathbf{c m}^{-1}\right)$ & Gugus Fungsi \\
\hline $675-995$ & $\mathrm{C}=\mathrm{H}$ (Alkena) \\
$690-900$ & $\mathrm{C}-\mathrm{H}$ (Cincin Aromatik) \\
$1050-1300$ & $\mathrm{C}-\mathrm{O}$ (Alkohol/Eter/Asam Karboksilat/Ester) \\
$1340-1470$ & $\mathrm{C}-\mathrm{H}$ (Alkana) \\
$2850-2970$ & $\mathrm{C}-\mathrm{H}$ (Alkana) \\
$3200-3600$ & $\mathrm{O}-\mathrm{H}$ (Alkohol ikatan hidrogen/Fenol) \\
$3300-3500$ & $\mathrm{~N}-\mathrm{H}$ (Amina/amida) \\
\hline
\end{tabular}

\section{Rendemen Fraksi Etanol dan Heksana}

Rendemen merupakan persentase senyawa yang didapatkan dari hasil ekstraksi terhadap berat bahan yang digunakan. Perhitungan rendemen didasarkan pada berat kering (bk) bahan. Data hasil rendemen ekstrak fraksi etanol daging biji palem putri dapat dilihat pada Gambar 2. Rendemen ekstrak etanol mengalami peningkatan seiring dengan lama waktu maserasi yang dilakukan. Peningkatan rendemen terjadi baik pada daging biji segar maupun daging biji kering. Hasil analisis ragam menunjukkan bahwa perlakuan pengeringan, lama waktu maserasi dan interaksi keduanya berpengaruh nyata terhadap rendemen ekstrak kasar fraksi etanol $(\alpha=0.05)$. Pengeringan dan lama waktu ekstraksi menentukan besarnya rendemen ekstrak dari pelarut ganda etanol-heksana yang dihasilkan. Pengeringan pada suhu $50^{\circ} \mathrm{C}$ diduga mampu merusak jaringan, dinding dan membran sel daging biji palem putri. Lewicki (1998) mengemukakan bahwa pengeringan dapat merusak dinding sel tanaman yang menyebabkan terbentuknya rongga dan meningkatkan porositas dari dinding sel. Kerusakan tersebut diduga membuat pelarut lebih mudah kontak dengan isi sel dan pelarutannya dapat berlangsung lebih efektif dibandingkan bahan segar. Senyawa yang diekstrak akan semakin banyak seiring lama waktu kontak yang terjadi antara bahan dan pelarut. Arrasyid (2006) yang melakukan penelitian terhadap daun Binahong juga melaporkan bahwa semakin lama waktu maserasi maka rendemen dari ekstrak yang dihasilkan akan semakin besar. 


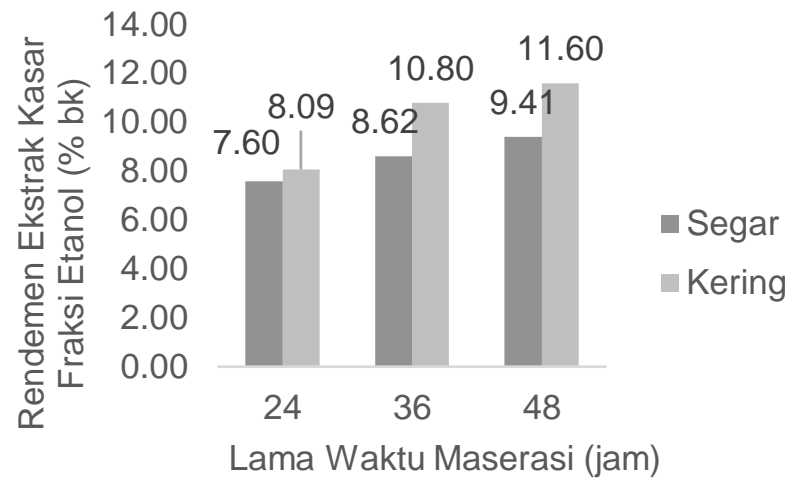

Gambar 2. Rendemen Ekstrak Kasar Fraksi Etanol Daging Biji Palem Putri Menggunakan Pelarut Ganda Etanol dan n-Heksana dengan Maserasi 24-48 jam

Data hasil rendemen ekstrak fraksi heksana daging biji palem putri dapat dilihat pada Gambar 3.

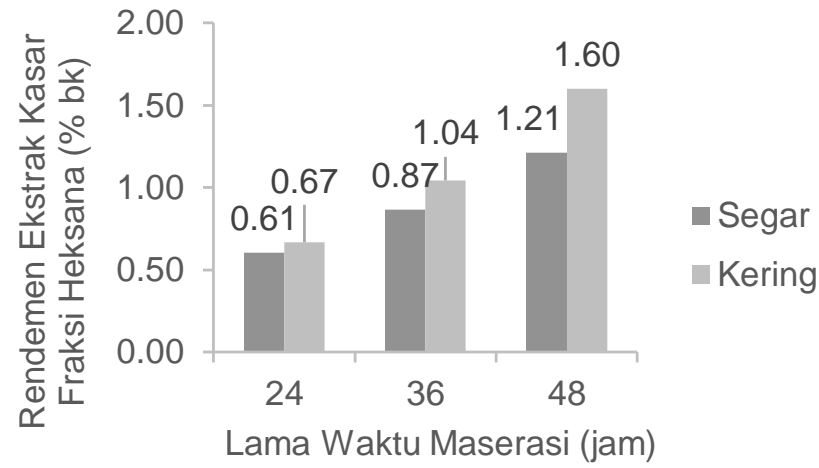

Gambar 3. Rendemen Ekstrak Kasar Fraksi Heksana Daging Biji Palem Putri Menggunakan Pelarut Ganda Etanol dan n-Heksana dengan Maserasi 24-48 jam

Hasil yang didapatkan pada rendemen fraksi heksana serupa dengan rendemen fraksi etanol, dimana daging biji kering dan semakin lama waktu maserasi menghasilkan rendemen yang lebih tinggi. Hasil analisis ragam menunjukkan bahwa perlakuan pengeringan, lama maserasi dan interaksi keduanya berpengaruh nyata terhadap rendemen ekstrak kasar fraksi heksana ( $\alpha=0.05)$. Menurut Omusuli et al. (2017) yang melakukan ekstraksi biji kelor menggunakan pelarut heksana menyebutkan bahwa rendemen ekstrak heksan dengan metode pengeringan lebih besar bila dibandingkan dengan bahan segarnya. Pengeringan mampu meningkatkan efisiensi dari ekstraksi heksana karena kandungan air yang mengganggu proses ekstraksi telah teruapkan. Proses ekstraksi ini akan semakin optimal seiring dengan meningkatnya lama waktu ekstraksi. Ayoola et al. (2014) yang melakukan penelitian tentang biji mimba menggunakan pelarut heksana menyebutkan bahwa semakin lama waktu ekstraksi yang digunakan maka semakin besar rendemen yang dihasilkan. Hal ini dikarenakan waktu kontak antara bahan dan pelarut semakin besar.

\section{Analisis Kuantitatif Fraksi Etanol Daging Biji Palem Putri}

\subsection{Total Fenol}

Total fenol ekstrak etanol kasar dan ekstrak etanol kering daging biji palem putri disajikan pada Gambar 4. 


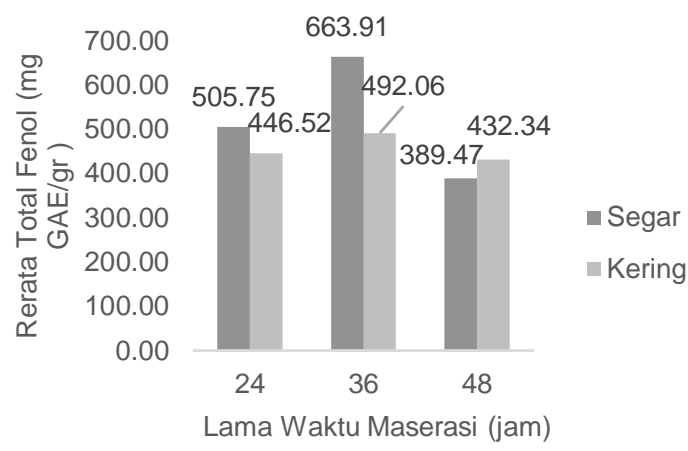

(a)

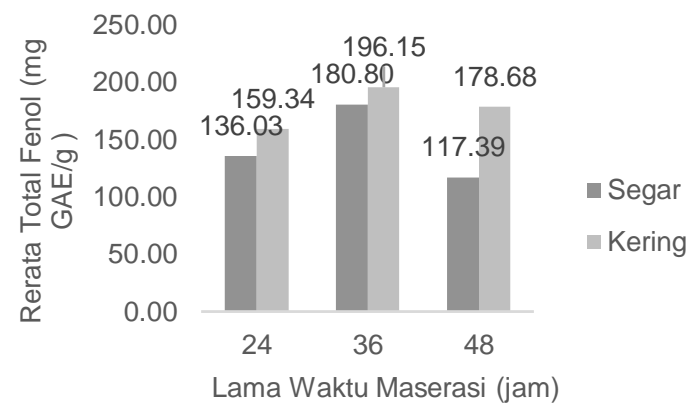

(b)

Gambar 4. Total Fenol Ekstrak Fraksi Etanol Daging Biji Palem Putri dengan Pelarut Ganda Etanol dan n-Heksana dengan Maserasi 24-48 jam: (a) Ekstrak Kasar dan (b)

Ekstrak Kering

Hasil penelitian menunjukkan total fenol didalam pelarut etanol $70 \%$ mengalami peningkatan selama maserasi dari 24 jam ke 36 jam, namun mengalami penurunan setelah lama waktu ekstraksi 48 jam. Polanya hampir serupa untuk sampel daging biji segar maupun daging biji kering. Pada pengaruh pengeringan, didapatkan hasil bahwa penggunaan daging biji kering menghasilkan rerata total fenol lebih tinggi bila dibandingkan dengan daging biji segar.

Hasil analisis ragam menunjukkan bahwa perlakuan pengeringan dan lama waktu maserasi berpengaruh nyata $(\alpha=0.05)$ terhadap total fenol ekstrak etanol daging biji palem putri dan terdapat interaksi antara kedua faktor tersebut.Total fenol ekstrak etanol kering lebih kecil bila dibandingkan dengan ekstrak etanol kasar daging biji palem putri. Total fenol yang rendah pada ekstrak etanol kering terjadi karena pengaruh perlakuan evaporasi dan perlakuan kering anginkan pada ekstrak tersebut. Menurut Vatai et al. (2009) yang melakukan penelitian terhadap total fenol buah elderberry, senyawa fenolik sangat rentan dan sensitif terhadap degradasi. Degradasi yang terjadi pada senyawa bioaktif sebagian besar diakibatkan oleh panas, oksigen, dan cahaya. Perlakuan kering anginkan menyebabkan kontak yang cukup lama antara kering dengan oksigen yang dapat membuat total fenol bahan terdegradasi.

Seperti telah dikemukakan, pengeringan dengan udara panas $50^{\circ} \mathrm{C}$ diduga mampu merusak dinding dan membran sel sehingga proses ekstraksi dari pelarut dapat berlangsung lebih efektif dibandingkan bahan segar. Menurut Arcan (2009), kandungan total fenol pada sampel kering lebih besar dibandingkan dengan bahan segarnya. Hal ini dapat terjadi karena pengeringan dapat merusak struktur dinding sel sehingga senyawa lebih mudah terdifusi keluar sel. Difusi yang semakin lama membuat total fenol yang terekstrak semakin besar. Namun maserasi yang terlalu lama dapat menyebabkan kerusakan senyawa terekstrak. Menurut Cikita et al. (2016) dalam Kemit dkk (2015) mengemukakan waktu ekstraksi yang melewati waktu optimum berpotensi meningkatkan kerusakan senyawa-senyawa yang terekstrak karena penguapan.

\subsection{Total Flavonoid}

Total Flavonoid ekstrak kering fraksi etanol daging biji palem putri disajikan pada Gambar 5. Hasil penelitian menunjukkan total flavonoida didalam pelarut etanol mengalami peningkatan selama maserasi dari 24 jam ke 36 jam, namun mengalami penurunan pada maserasi 48 jam. Polanya hampir serupa baik untuk sampel daging biji segar maupun daging biji kering. Penggunaan daging biji kering menghasilkan rerata total flavonoida lebih tinggi bila dibandingkan dengan daging biji segar. 


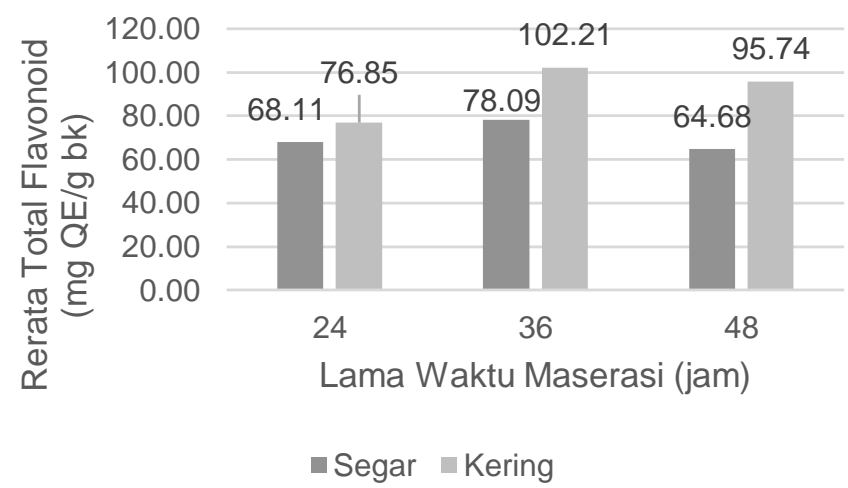

Gambar 5. Total Flavonoida Ekstrak Kering Fraksi Etanol Daging biji palem putri Menggunakan Pelarut Ganda Etanol dan n-Heksana dengan Maserasi 24-48 jam

Hasil analisis ragam menunjukkan bahwa perlakuan pengaruh pengeringan dan lama waktu ekstraksi berpengaruh nyata $(\alpha=0.05)$ terhadap total flavonoid daging biji ekstrak etanol kering dan terdapat interaksi antara kedua faktor tersebut. Menurut Momuat dkk. (2015) flavonoid memiliki hubungan positif dengan polifenol dimana bahan kering memiliki rerata kandungan flavonoida yang lebih tinggi bila dibandingkan dengan bahan segar yang digunakan. Hal ini dikarenakan flavonoid merupakan salah satu senyawa metabolik sekunder golongan fenolik yang paling banyak ditemukan pada tanaman, sehingga sifat senyawa yang dimiliki oleh flavonoid sangat mirip dengan polifenol.

\subsection{Kadar Saponin} Gambar 6.

Kadar saponin ekstrak kering fraksi etanol daging biji palem putri dapat dilihat pada

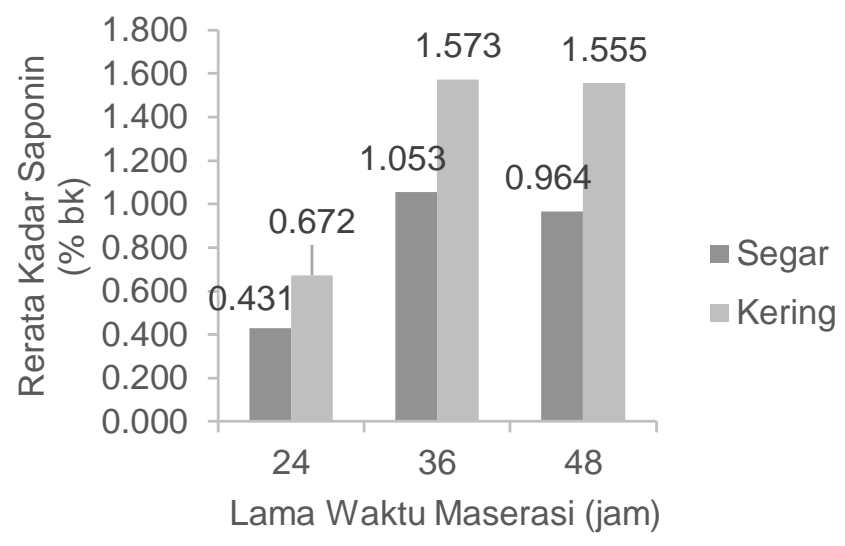

Gambar 6. Kadar Saponin Ekstrak Kering Fraksi Etanol Daging Biji Palem Putri Menggunakan Pelarut Ganda Etanol dan n-Heksana dengan Maserasi 24-48 jam

Kadar saponin ekstrak etanol terlihat mengalami peningkatan pada ekstraksi 36 jam pertama dan selanjutnya menurun. Pola kenaikan dan penurunan ini terlihat pada sampel segar dan kering. Pada pengaruh pengeringan, didapatkan hasil bahwa penggunaan daging biji kering menghasilkan rerata kadar saponin lebih tinggi bila dibandingkan dengan daging biji segar. Hasil analisis ragam menunjukkan bahwa perlakuan pengaruh pengeringan dan lama waktu maserasi memiliki pengaruh nyata $(\alpha=0.05)$ terhadap kadar saponin ekstrak etanol kering daging biji palem putri, dan terdapat interaksi antar kedua faktor

Kadar saponin bahan kering lebih tinggi dibandingkan dengan bahan segar. Menurut Lee et al. (2014) kadar saponin cenderung meningkat dengan perlakuan pengeringan suhu rendah, namun apabila menggunakan suhu tinggi maka saponin akan cenderung menurun. 
Penggunaan pengeringan suhu $50^{\circ} \mathrm{C}$ dapat dinyatakan sebagai pengeringan suhu rendah, oleh sebab itu pengeringan ini tidak mempengaruhi struktur saponin. Ekstraksi ini akan lebih optimal seiring dengan meningkatnya waktu ekstraksi yang dilakukan. Namun seiring banyaknya zat yang terlarut dalam etanol, maka kemampuan etanol dalam dalam melarutkan zat akan cenderung menurun. Hal tersebut dinyatakan oleh Koirewoa (2012) yang melakukan penelitian pada daun bluntas menyatakan bahwa kemampuan etanol dalam melarutkan senyawa akan cenderung menurun seiring dengan terjadinya kejenuhan setelah melewati waktu optimumnya.

\subsection{Aktivitas Antioksidan}

Aktivitas antioksidan merupakan kemampuan senyawa dalam mengurangi aktivitas radikal bebas. Aktivitas antioksidan diukur dengan panjang gelombang $521 \mathrm{~nm}$ menggunakan larutan standar DPPH sebagai radikal bebas. Aktivitas antioksidan dinyatakan dalam persen inhibisi. Aktivitas antioksidan ekstrak etanol kasar dan ekstrak etanol kering daging biji palem putri disajikan pada Gambar 7.

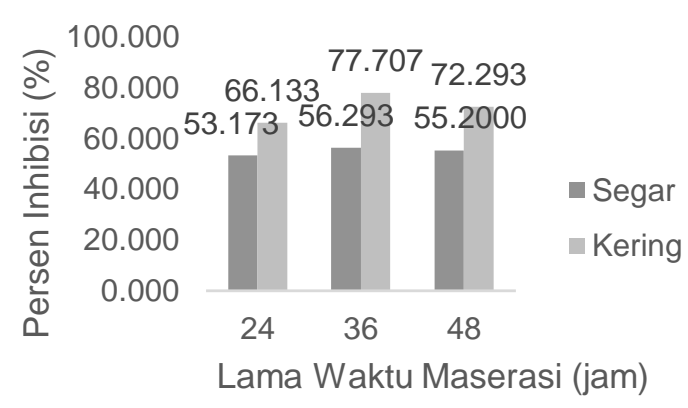

(a)

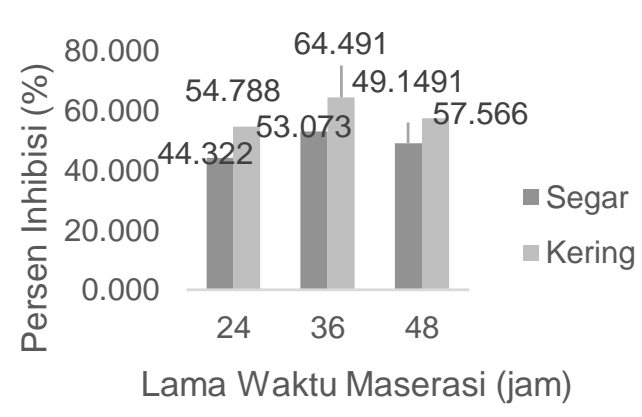

(b)

Gambar 7. Aktivitas Antioksidan Ekstrak Fraksi Etanol Daging Biji Palem Putri dengan Pelarut Ganda Etanol dan n-Heksana dengan Maserasi 24-48 jam, (a) Ekstrak Kasar dan (b) Ekstrak Kering

Aktivitas antioksidan ekstrak etanol kering lebih kecil bila dibandingkan dengan ekstrak etanol kasar biji palem putri. Aktivitas antioksidan yang rendah pada ekstrak etanol kering mengindikasikan adanya kerusakan senyawa antioksidan selama penguapan dan pengeringan ekstrak kasar menjadi ekstrak kering. Aktivitas antioksidan sangat ditentukan oleh senyawa yang terkandung dalam ekstrak. Perlakuan kering anginkan membuat ekstrak etanol kering terpapar dengan oksigen cukup lama. Reaksi oksidasi senyawa bioaktif dengan oksigen dapat mengurangi kemampuan senyawa tersebut dalam menetralkan radikal DPPH, sehingga aktivitas antioksidannya akan menurun.

Hasil penelitian menunjukkan bahwa sampel kering menghasilkan aktivitas antioksidan yang lebih tinggi daripada yang segar. Pola besarnya aktivitas antioksidan ekstrak etanol serupa dengan pola kadar fenol, flavonoid dan saponin daging biji palem putri. Aktivitas tertinggi diperoleh dari maserasi $36 \mathrm{jam}$, baik pada sampel segar maupun kering. Hasil analisis ragam menunjukkan bahwa perlakuan pengeringan dan lama waktu maserasi masing-masing berpengaruh nyata tetapi tidak ada interaksi keduanya terhadap aktivitas antioksidan ekstrak kasar dan kering fraksi etanol daging biji palem putri pada $\alpha=0,05$.

Korelasi ganda antara total fenol dan kadar saponin terhadap aktivitas antioksidan disajikan pada Gambar 8. Nilai korelasi ganda total fenol dan kadar saponin terhadap aktivitas antioksidan didapatkan sebesar 0.8945 , dan didapatkan koefisien determinasi sebesar 0.8001 . Hal ini menunjukkan bahwa total fenol dan kadar saponin mempengaruhi aktivitas antioksidan sebesar $80.01 \%$. 


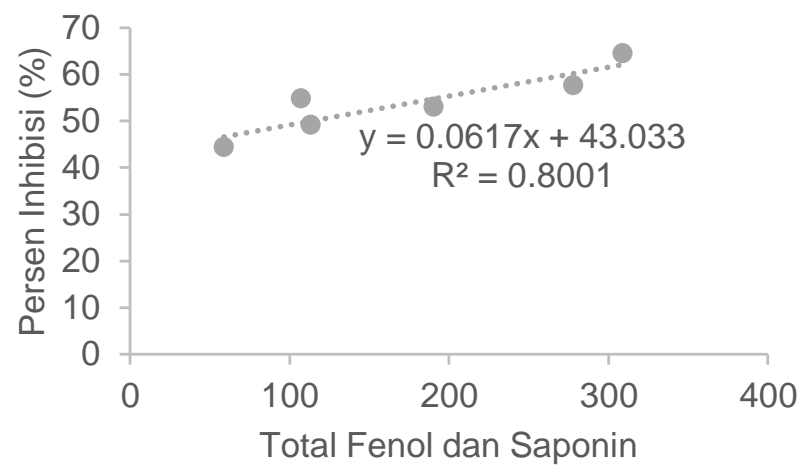

Gambar 8. Korelasi Ganda Total Fenol dan Saponin terhadap Aktivitas Antioksidan Ekstrak Fraksi Etanol Daging Biji Palem Putri dengan Pelarut Ganda Etanol dan n-Heksana dengan Maserasi 24-48 jam

\subsection{Analisis Total Karotenoida}

Pengujian total karoten ekstrak etanol daging biji palem putri dilakukan menggunakan sampel terbaik dalam penelitian ini, dimana sampel yang digunakan adalah sampel kering dengan perlakuan lama waktu ekstraksi selama 36 jam. Hasil penentuan menunjukkan bahwa total karoten ekstrak kering etanol bii palem putri sebesar 0,03 $\mu \mathrm{g} / \mathrm{gram}$ yang jauh berbeda dengan yang dilaporkan oleh peneliti terdahulu yang sebasar $0.4 \pm 0.2 \mu \mathrm{g} / \mathrm{gram}$ (Silva et al., 2014).

\section{SIMPULAN}

Lama waktu maserasi dan jenis bahan segar dan kering berpengaruh nyata terhadap rendemen pelarut ganda fraksi etanol dan heksana. Nilai rendemen tertinggi didapatkan dengan maserasi 48 jam bahan segar, baik untuk fraksi etanol (11.6 \%) maupun heksana $(1.6 \%)$.

Ekstrak etanol daging biji palem putri menunjukkan bahwa ekstrak etanol daging biji palem putri positif mengandung senyawa bioaktif fenol, flavonoida, dan saponin jenis triterpenoid. Analisis gugus FTIR memperkuat hasil uji kualitatif secara kimiawi. Lama waktu maserasi dan jenis bahan segar dan kering berpengaruh nyata terhadap kadar senyawa bioaktif fenol, flavonoida, saponin, dan aktivitas antioksidan. ekstrak etanol daging biji palem putri.

Ekstrak daging biji palem putri dengan Perlakuan terbaik didapatkan dengan maserasi 36 jam pada daging biji kering palem putri, dengan rendemen ekstrak etanol $10.8 \%$, rendemen ekstrak heksana $1.04 \%$, dan karakteristik ekstrak fraksi etanol berupa total fenol sebesar 196.15 mgGAE/gram, total flavonoida sebesar $102.21 \mathrm{mgQE} / \mathrm{gram}$, kadar saponin sebesar $1.57 \%$, aktivitas antioksidan sebesar $64.49 \%$, dan total karotenoida sebesar $0.03 \mu \mathrm{g} / \mathrm{gram}$.

\section{DAFTAR PUSTAKA}

Adawiah. 2016. Kandungan Fitokimia dan Bioaktivitas Ekstrak Metanol Biji Palem Putri (Veitchia merillii). Jurnal Kimia Valensi 2:1, 63-70

Agustina, Wulan, Nurhamidah, dan Dewi H. 2017. Skrining Fitokimia Dan Aktivitas Antioksidan Beberapa Fraksi Dari Kulit Batang Jarak (Ricinus communis L.). Jurnal Pendidikan dan IImu Kimia 1:2, 117-122

Anthikat, Michael A., dan Kinsalin, V. A., Ignacimuthu S. 2014. Antifungal Activity of Areca catechu L. Int. Journal Pharmaceutical Clinic Science 4:1,1-3 
Hamzah, A., Muhammad, H., Ummu, B., Darmawi, Maryam, dkk. 2016. Aktivitas Antelmintik Biji Veitchia Merrillii terhadap Ascaridia Galli Secara In Vitro. Traditional Medicine Journal $21: 2,55-62$

Krisyanella, Nana, S., dan Harrizul R. 2013. Pembuatan dan Karakterisasi serta Penentuan Kadar Flavonoid dari Ekstrak Kering Herba Meniran (Phyllanthus niruri L.). Jurnal Farmasi Higea 5:1, 6-14

Lee, Byung, J., Young, S. C. 2014. Effects of Drying Temperature on the Saponin and Free Sugar Contents of Platycodon grandiflorum Radix. Korean J. Food Sci. Technol 46:6, 769 772

Leyes, Eduardo, A., Rodríguez, L., Roxana, V. M., Víctor, L. González C., Roxana, D. L. C. S. P., and David, M. D. Y. Á. T. L. S. 2013. Contenido De Ácidos Grasos En La Fracción Lipídica De Frutos De Tres Arecaceae Cultivadas En Cuba. Journal Ciencias Químicas 44, 23-28

Molyneux. P. 2004. The Use Of Stable Free Radical Diphenylpicrylhydrazyl (DPPH) for Estimating Antioxidant Activity. Journal Science and Technology 26:2, 211-219

Momuat, Lidya, I., Edi, S., Olha, R., Aneke, K., Hasan, D. 2015. Perbandingan Senyawa Fenolik dan Aktivitas Antioksidan Antara Sagu Baruk Segar dan Kering. Jurnal Chem. Prog. 8:1, 20-29

Ningrum, Maya, P. 2017. Pengaruh Suhu dan Lama Waktu Maserasi terhadap Aktivitas Antioksidan Ekstrak Metanol Rumput Laut Merah (Eucheuma Cottonii). Thesis. Universitas Brawijaya. Malang

Olatunya, A. M. dan Akintayo, E. T. 2017. Evaluation of The Effect of Drying on The Chemical Composition and Antioxidant Activity of The Essential Oil of Peels from Three Species Of Citrus Group. International Food Research Journal 24:5, 1991-1997

Pandey, A. and Shalini, T. 2014. Concept of Standardization, Extraction and PrePhytochemical Screening Strategies for Herbal Drug. Journal of Pharmacognosy and Phytochemistry 2:5, 115-119

Rahmah, I. M. 2017. Pengaruh dari Ekstrak Kulit Batang Tanaman Lindur (Bruguiera Gymnorrhiza) Segar dan Kering terhadap Sel Hela. Thesis. Universitas Brawijaya. Malang

Redha, A. 2010. Flavonoid: Struktur, Sifat Antioksidatif dan Peranannya Dalam Sistem Biologis. Jurnal Belian 9:2, 196-202

Sari, M. 2011. Identifikasi Protein Menggunakan Fourier Transform Infra Red. Skripsi. Universitas Indonesia. Depok

Sharma, G. N. 2011. Phytochemical Screening and Estimation of Total Phenolic Content in Aegle marmelos Seeds. International Journal of Pharmaceutical and Clinical Research $2: 3,27-29$

Vatai, T., Skerget, M., and Knez, Z. 2009. Extraction of Phenolic Compounds from Elder Berry and Differentgrape Marc Varieties Using Organic Solvents and/or Supercritical Carbondioxide. J. Food Eng. 